\title{
PHYSICAL EDUCATION TEACHER AS A REFLECTIVE PRACTITIONER STUDYING AT A SPORTS UNIVERSITY
}

\section{Laura Tumynaitė}

Lithuanian Sports University, Kaunas, Lithuania

\begin{abstract}
ANNOTATION
With the rapid advancement and changes in students' generation, the society needs improvements in the process of the preparing physical education teachers. The process of the preparation requires the development of a practically, individually, creatively, critically minded physical education teacher capable of active and independent problem solving in practice. The article focuses on the process of preparation and improvement of the curriculum for physical education teachers in Lithuania. The aim of the article is to update and compare a new European dimension - a reflective teaching model that encourages the analysis of past activities and the construction of new activities.
\end{abstract}

Keywords: physical education teacher, reflexive practice.

\section{INTRODUCTION}

Relevance of the theme. Philosophical and pragmatic questions about teacher training are becoming increasingly debatable. The emphasis is on teacher training at the initial level. In the world, there is a debate about the meaning of an educated physical education teacher, the criteria of which should be used to describe it. Obviously, "teaching how to train" is a complex task that requires a lot of different competencies for teachers and professionals (Hoban et al., 2005). The complexity is that it is necessary to prepare a specialist able to study independently, so the most urgent question is "how to train." This process becomes troublesome when the teacher starts working on the peculiarities of his/her activity during the work practice. He/she needs help from other professionals or must be able to discover, analyze the problem and solve it.

The perception and role of the educational process is diverse among scholars, academics, politicians and educators themselves. For example, the behaviorist paradigm discourse sees a teacher as a technique. The role of teacher-technician is to implement the curriculum through a designated learning program. A number of politicians support this view (Apple, 1986; Cochran-Smith, 1993; Zeichner, 2001). The implementation of the curriculum requires a lot of competencies, time, ideas that emerge from work practice. The article focuses on the development and improvement of the curriculum for physical education in Lithuania. The new European dimension - a reflective teaching model that promotes analysis of past activities and the construction of new activities - is relevant here. The concept of reflective model - reflection is discussed, the significance of its practical application and its potential in the study process and practical work of the educator of the physical education are analyzed.

Research problem. As the European Strategy Papers state and the Bologna Process is the main driver of higher education, it is important to improve the study process, especially among students. The main challenges of higher education require a fully-educated specialist for a broad labor market and its competition, and in important issues regarding lifelong learning it is important to 
develop reflexive practices that continuously improve the competences required for future professional activities. Developing reflexive practices at a university and enabling students to reflect on them is a major problem: there is little or no possibility for students to reflect on their own experiences, thus forming the competencies needed for reflection, which are needed for future professionals (Loughran, 1996). The problematic issue is how to train a physical education teacher as a reflexive practitioner at a sports university?

Problem exploration. The methodology of the article is revealed by the reflective method, promoting and learning to analyze and design the activities of the physical education teacher. Reflective models are discussed on the basis of the reflection stage of learning through the experience cycle (Bubnys, 2007).

The aim of the study was to reveal theoretical assumptions about the application of the reflective model in the training of physical education teachers at a sports university.

Object of the research was training of the reflective practitioner.

\section{METHODOLOGY}

The methodology of the article is based on the reflective method, promoting and learning to analyze and design the activities of a physical education teacher. Reflective models are discussed on the basis of the reflection stage of learning through the experience cycle (Bubnys, 2007).

Concept of a reflecting practitioner. Reflection is presented (Jovaiša, 2007) as a way of thinking when a person critically analyzes, understands and senses comprehension or generalized forms and assumptions, the structure and characteristics of his spiritual world. Reflection of a teacher of physical education as a specialist is understood as self-knowledge (the perception and assessment of thoughts, feelings, attitudes, and actions), as well as the desire and ability to know personal physical, mental and spiritual condition (Jovaiša, 2007), which contribute to professional development. "Reflection is the turning point of thinking from the observation of the external world to self-observation. An internal look at ourselves as a moral object" (Vyšniauskienė, Minkute, 2008, p. 257). According to P. Jarvis (2001), reflection is perceived as an act of analysis that involves two aspects: the first is reflection as a natural personal trait of a person, in self-analysis; the second aspect is an external reflection, which includes activity and its context, analysis of the actions, attitudes and values involved in the activities. The correlated tendencies of the inner world and the external environment stimulate the reflection of a person, causing certain tensions. This condition encourages a person to rely on his / her own experience, to look for ways to solve common problems. This proves that the reflective practice is based on the model created by an American scientist D. Kolb. The latter has developed a theory the essence of which is the use and change of one's own experience by mastering and creating new knowledge and new experience by replacing the acquired one. It was created by combining theories developed in philosophy, psychology and education.

D. Kolb (1984) presented a model of practical learning and proposed to integrate the experience of the teaching process, the perceived behavior, and the application of knowledge into everyday activities. According to the scholar, the learning process must comprise the entire practical knowledge luggage, since individual items are not worthless. He called the process of learning a 
cyclical one. It can be argued that the practical application of knowledge is impossible without conclusions.

The development of a teacher of physical education as a reflexive practitioner. The educated generation is rapidly changing and improving, and as a result, there is a need for society to improve the process of preparing physical education teachers. The task is to prepare a practicing, individual, creative, critical thinking teacher of physical education, able to actively and independently solve emerging problems in practical work activities.

The philosophy of learning, based on reflection, begins at a high school with day-to-day experience. It is important for students to learn that learning has meaning for them, and the educator must feel the meaning of their work (Grendstad, 1999). The study process and the learning program declare the practical skills and the competences required for the professional work of a physical education teacher. The question that is relevant and considered in working time distribution is how to integrate a reflective model into the learning process that requires a lot of competences and practical skills (Wallace, 1991). Such learning model is cyclical and integrates the outer and inner worlds. No less important is the close connection between theory and practice here. An important part of the model, its separate parts are completely irrelevant and inactive. Looking at the whole model of reflective education, vocational training and application of it in the process of preparing a physical education teacher, one can notice the declared importance of practical and theoretical knowledge. It is especially important that the process of preparing physical education teachers reflects all the components prevailing in the programs in this field. In this way, the educator of physical education will be educated not only in direct professional activity, but also as a person.

Combining different patterns of reflective practice, R. Bubnys (2007) distinguished the conditions necessary for reflection of the teacher of physical education as a reflexive practice: it is important for the student to be able to actively participate in reflection activities: it is important to learn how to actively plan voluntary activities, to set goals and achieve them; to create conditions for learning from personal errors; to create conditions for access to information sources; to emphasize the deep-rooted approach of physical education teacher to the learning content acquisition, to help form the knowledge structure and understanding of the teacher of physical education, which is based on hypothetical relationships (Seibert, Daudelin, 1999).

A significant part of the educational process is the mentor who coordinates the educational process. It has already been mentioned that the concept of relaying occurs during the reflection of experience. By developing a physical education teacher as reflexive practitioner, it is important to create conditions for him/her to separate from the outside and expand the inner space, encourage him/her to stop thinking in order to eliminate unpleasant feelings and analyze them. The meaning of "space" here means a sufficient amount of time, an adequate relationship between mentor and educator, trust in the possibilities of the future reflective practitioner, and the readiness and selfreflection of the educator and educator for the reflection process itself. Teachers who seek to practice reflection in their work with students should take into account the context and personalize their approaches based on the specific situation and needs of the student. The teacher, in a relationship 
with the student, intervenes openly or indirectly and uses the student's knowledge to facilitate reflection (Ramsey, 2003).

It is also important that any failure should not be considered incompetence or weakness. Mistakes are very important in the learning process, because it encourages reflection and aims to remove obstacles. This creates a sense of security for students and eliminates fear of risk. In developing the discussion on what conditions are needed to develop a teacher of physical education, it is important to mention the learner's autonomy and autonomy, to create a clear motivational system, and to provide an effective feedback on the improvement of teacher competences.

Physical education as a reflective practice in the process of education has to dominate the environment, creating favorable conditions for the development of reflection and development (Seibert, Daudelin, 1999). The basic conditions for developing a physical education specialist as reflexive practice are learner autonomy and autonomy, a clear system of incentives and activities priorities, an effective feedback and a comprehensive opportunity for the participants in the education process to interact and collaborate.

\section{RESULTS AND DISCUSSION}

At a sports university, creating the climate for students to reflect, there is a problem: students have too little or no systematic reflection on their own modeled or surviving experience, forming a reflection competence that is especially needed for them as future professionals (Loughran, 1996). In a discourse of the reflective process of education, it is important for the student to understand what they are learning (Nicholls, 2001). The whole process of reflective practice training allows the student to learn more, to structure the material in the way that is convenient for him, to promote metacognitive processes. If students are encouraged to reflect, they are in some way challenging, so it is very important to ensure the right conditions for the development of this process.

The organization of the study process, using the reflective model, has two important aspects. The first is the right conditions for an uninterrupted reflection of personal and professional experience. Student's knowledge, skills gained, perception of values must interact with the competence of the teacher of the physical education corresponding to the same provisions. The second is the right conditions for students to solve and analyze their problems in practical activities by contacting the practitioners. Studies must be organized by integrating the reflective approach.

The philosophy of learning, based on reflection, begins at a high school with day-to-day experience. It is important for students to learn that learning has meaning for them, and the educator must feel the meaning of his work (Grendstad, 1999).

Reflective practice in the structure of education should reflect not only aspects of the practice, such as intellectual, cognitive and meta-cognitive, but also spiritual, moral and emotional as unidentified aspects that reflect the inner life of the teachers of physical education. The structure has five different stages / levels of reflection: philosophy, principles, theory, practice, and practice. In the whole educational process, future physical education teachers are encouraged not only to describe a particular phenomenon or process, but also to adopt profound assumptions at every level of reflection. By this method, educators in physical education will be able to see their professional (or even 
personal) world through the magnifying glass and who formed their professional lives, as they become more aware of their philosophy, principles, theories, practices, and the effects of such an impact inside or outside the world (Farrell, 2016).

It is especially important to create conditions (Lipinskiene, 2002) for the reflection practitioner at a sports university. The learner's autonomy is the first condition that needs to be fulfilled in order to make reflective practice not only a strong physical education specialist but also fully prepared to grow as an individual who himself knows who clearly justifies the learning paradigms and their meanings in the specifics of work. A constant relationship with the teacher is important in the process of education, so a clear incentive and operational priority system must be created that prevents the learner from directing the accumulated information in the wrong direction. Effective feedback is like a teacher's business card, which allows the teacher to disclose the knowledge of the subject, and allow the student to structure the information received and its application. Also, in all educational process pre-emptive relations must prevail so that the student does not feel tension, create his or her own learning space, thus creating a comprehensive opportunity for the participants in the education process to interact and collaborate.

Teachers can help learners to become reflective thinking by applying the following steps (Westberg et al., 2001):

- Encouraging students to have valuable experience to be considered;

- Student tracking activities;

- Time and place planning for reflection;

- Creating mutual trust;

- Students' prior experience and focus on reflection

The word university requires the preparation of comprehensive universal specialists. In order to act as a reflective model, it is important to combine the whole body of theoretical knowledge obtained at the Sports University and the set of practical skills that is required for the professional work of the teacher of physical education. It is very important that the fundamentals needed to implement a reflective model at the university already exist, it is only necessary to apply it in the context of the realization of the time and study program. Equally important is the parity relationship between a student and a teacher, as this is a university's traditional value, uniting the academic community united and successful in liberal education. In this case, the lecturer should not attempt to transfer knowledge, as a knowledge expert in this field, but to help the student understand the challenges they face and their ability to deal with the professional activity of the teacher of physical education through personal experiences and competences. This is the foundation for educating a physical education teacher as a reflective practice at a sports university.

After transition from elite to mass education, the latter states in its formal expression the possibilities of satisfying material interests of the society: higher education institutions have to effectively prepare narrow profile specialists, prevailing applied research, which quickly gives tangible results, etc. On the other hand, by its very nature, massive higher education seeks to free up the broadest and varied way of thinking of the layers of society up to intellectual emancipation (it cannot be done without the quality of university higher education) and enable reflection, analysis of 
their own actions, which means self-management of life and professional activities in the fields of knowledge and information in society. As a result, a teacher of physical education, reflecting their practice at a sports university, must go beyond the diploma, but with a lot of knowledge luggage to reflect. As a result, it is important for a young specialist to devise basic knowledge from the first year of studies, and further and deeper knowledge, to formulate tasks that allow them to reflect.

\section{CONCLUSIONS AND PERSPECTIVES}

It is important to reform the academic and practical content of studies by creating reflexive physical education teacher training, creating conditions for the reflection of personal and professional identity, developing and integrating reflective model approaches into the content of studies, developing teacher competencies, developing reflective analysis and cooperation and interaction with students in the areas of knowledge, skills and valuables. The reflective model in vocational training of specialists in the work of physical education pedagogues creates conditions for the development of changes and the search for alternative ways to attract students to enjoy physical activity and fulfill the goal of physical education - to be physically active not only within the school, but also outside it. This goal is being developed at a university where universality is particularly emphasized.

The argument for the purpose of physical education is part of the research as a training tool for the training of physical education teachers. A combination of practical work and research is necessary as it gives the educators the opportunity to learn to understand their knowledge and maintain opinions. It would also help improve the sometimes extremely good status of the teacher of physical education and enhance the knowledge of the work of a physical education teacher in the practice of professional work.

\section{REFERENCES}

1. Apple, M. W. (2006). Educating the "Right" Way: Markets, Standards, God, and Inequality. Taylor \& Francis.

2. Bubnys, R. (2007). Reflektyvaus mokymo(si) metodu diegimo aukštojoje mokykloje metodika: refleksija kaip besimokančiuju asmeninès ir profesinès raidos didaktinis metodas. Šiaulių valstybinè kolegija.

3. Cochran-Smith, M., Lytle, S. L. (Eds.). (1993). Insideloutside: Teacher Research and Knowledge. Teachers College Press.

4. Farrell, T. C. (2016). TESOL, a profession that eats its young! The importance of reflective practise in language teacher education. Iranian Journal of Language Teaching Research, 4 (3), 97-107.

5. Grendstad, G. (1999). A political cultural map of Europe. A survey approach. GeoJournal, 47 (3), $463-$ 475 .

6. Grendstad, G. (1999). The new ecological paradigm scale: Examination and scale analysis.

7. Hoban, J. D., Lawson, S. R., Mazmanian, P. E., Best, A. M., Seibel, H. R. (2005). The self-directed learning readiness scale: A factor analysis study. Medical Education, 39 (4), 370-379.

8. Jarvis P. (2001). Mokymosi paradoksai. Kaunas: VDU Švietimo studijųcentras. 
9. Jovaiša, L. (2007). Enciklopedinis edukologijos žodynas. Vilnius: Gimtasis žodis.

10. Kolb, D. A. (1984). Experiential Learning. Experience as the Source of Learning and Development. EngMclewood Cliffs, New Jersey: Prentice- Hall.

11. Lipinskienè, D. (2002). Edukacinè studenta igalinanti studijuoti aplinka: daktaro disertacija. Vilnius: Lietuvos edukologijos universitetas.

12. Loughran, J. J. (2002). Effective reflective practice: In search of meaning in learning about teaching. Journal of Teacher Education, 53 (1), 33-43.

13. Nicholls, S. (2001). Measuring the accessibility and equity of public parks: A case study using GIS. Managing Leisure, 6 (4), 201-219.

14. Ramsey, G. P. (2003). Race Music: Black Cultures from Bebop to Hip-Hop (Vol. 7). Univ of California Press.

15. Seibert, K. W., Daudelin, M. W. (1999). The Role of Reflection in Managerial Learning: Theory, Research, and Practice. Quorum Books.

16. Vyšniauskienè, D., Minkutè, R. (2008). Socialinès veiklos profesine etika. Kaunas: Technologija.

17. Wallace, M. J. (1991). Training Foreign Language Teachers: A Reflective Approach. Cambridge University Press.

18. Westberg, J. (2001). Helping learners become reflective practitioners. Education for Health: Change in Learning and Practice, 14 (2), 313-321.

19. Westberg, J., Jason, H. (2001). Fostering Reflection and Providing Feedback: Helping others Learn from Experience. Springer Publishing Company.

20. Zeichner, K. (2001). Educational action research. In Handbook of action research: Participative inquiry and practice. P. 273-283.

\title{
PHYSICAL EDUCATION TEACHER AS A REFLECTIVE PRACTITIONER STUDYING AT A SPORTS UNIVERSITY
}

\section{Laura Tumynaitė}

Lithuanian Sports University, Kaunas, Lithuania

\begin{abstract}
Research background. With the rapid advancement and changes in students' generation, the society needs improvements in the process of the preparing physical education teachers. The process of the preparation requires the development of a practically, individually, creatively, critically minded physical education teacher capable of active and independent problem solving in practice. The article focuses on the process of preparation and improvement of the curriculum for physical education teachers in Lithuania. The aim of the article is to update and compare a new European dimension - a reflective teaching model that encourages the analysis of past activities and the construction of new activities.
\end{abstract}


The aim of the research was to reveal theoretical assumptions about the application of the reflective model in the training of physical education teachers at a sports university.

Conclusions and perspectives: It is important to reform the academic and practical content of studies by creating reflexive physical education teacher training, creating conditions for the reflection of personal and professional identity, developing and integrating reflective model approaches into the content of studies, developing teacher competencies, developing reflective analysis and cooperation and interaction with students in the areas of knowledge, skills and valuables. The reflective model in vocational training of specialists in the work of physical education teachers creates conditions for the development of changes and the search for alternative ways to attract students to enjoy physical activity and fulfill the goal of physical education - to be physically active not only within the school, but also outside it. This goal is developed at a university where universality is particularly emphasized.

The argument for the purpose of physical education is part of the research as a training tool for the training of physical education teachers. A combination of practical work and research is necessary as it gives the educators the opportunity to learn themselves to understand their knowledge and maintain opinions. It would also help improve the sometimes extremely good status of the teacher of physical education and enhance the knowledge of the work of a physical education teacher in the practice of professional work.

Keywords: physical education teacher, reflexive practice. 